\title{
Att prioritera i socialtjänsten -Om kommunalt handlingsutrymme och beslutsfattande
}

\author{
MARIE WÖRLÉN
}

\begin{abstract}
Artikeln beskriver förutsättningar för, samt erfarenheter av prioriteringar i socialtjänsten. Studiens respondenter består av tjänstemän och politiker i sex svenska kommuner. Med prioriteringar avses på vilket sätt resurser fördelas mellan olika klientgrupper samt vilka klientgrupper som ämnas få ta del av resurser i första hand.
\end{abstract}

\section{Inledning}

I kölvattnet av de ekonomiska svårigheter som drabbade Sverige under 1990-talet fick en mängd kommuner svårigheter att få en budget i balans. Prioriteringar kom i och med detta att hamna på den politiska agendan på ett mer uttalat sätt än tidigare (Socialstyrelsen 2007a). Åren fram till finanskrisen i slutet av 2008 innebar överlag förbättringar för de svenska kommunerna, men nödvändigheten av tydliga och väl övervägda prioriteringar mellan olika verksamheter har trots detta etablerat sig som ett imperativ i det politiska arbetet. Uppfattningen att resurserna måste satsas

Marie Wörlén, doktorand, Institutionen för socialt arbete, Mittuniversitetet, Östersund där de behövs som mest samt där de gör störst verkan har stärkts genom åren, samtidigt som grundläggande värderingsfrågor fått och nu får förnyad aktualitet (Bergmark 1996). Politiskt finns skilda meningar om hur en ändamålsenlig, effektiv och på samma gång rättvis offentlig verksamhet skall bedrivas, samtidigt som det på kommunal nivå i det närmaste existerar konsensus om behovet av mer öppna och mer systematiska prioriteringar (Forsblom 2002). I offentlig sektor är prioriteringar alltså inget nytt - alla beslut avseende hur resurser skall fördelas innehåller prioriteringar och diskussioner kring tilldelning av resurser förs ständigt. I tider av ekonomisk nedgång framträder dock vikten av genomtänkta prioriteringar som särskilt påtaglig.

Empiriska studier avseende priorite- 
ringar inom socialtjänsten är ovanliga. Av faktiskt genomförda svenska studier på området (Bergmark 1995, Petersson 2006) framgår att det finns skillnader mellan politiker och tjänstemän och deras sätt att se på förutsättningar för och att arbeta med prioriteringar. Vidare framkommer att beslutsfattare på olika nivåer betraktar prioriteringar som svåra på grund av den mängd aspekter som måste tas i beaktande och den komplexitet som detta medför. Svårigheterna har också en mer känslobetonad sida då prioriteringar å ena sidan handlar om att tillgodose behov, men också att andra behov i förlängningen inte blir tillgodosedda (Bergmark 1996, 1997, Judge \& Mays 1994, Lund 2003).

Föreliggande artikel redovisar resultat från en enkätstudie gjord under hösten/ vintern 2006. Undersökningen har genomförts bland tjänstemän och politiker i socialtjänsten i sex svenska kommuner. I studien riktas fokus mot såväl faktiska erfarenheter av gjorda prioriteringsbeslut som uppfattningar om vad som i fortsättningen bör ges hög respektive låg prioritet. Vidare diskuteras de skilda förutsättningar som politiker och tjänstemän och olika tjänstemannagrupper har i arbetet med prioriteringar. Studiens syfte är att undersöka hur de studerade grupperna förhåller sig till prioriteringar och hur de väljer att prioritera vissa grupper framför andra. Vidare undersöks vilka faktorer som kan vara av betydelse för beslutsfattandet, samt hur tjänstemän och politiker uppfattar sitt eget inflytande över besluten. Artikeln innehåller en första redovisning av resultat från det FAS-finansierade projektet "Prioriteringar i socialtjänsten - en studie av resurs- fördelning, värdegrunder och kommunalt handlingsutrymme». I en serie kommande artiklar skall mer specifika frågeställningar avseende sådant som betydelsen av kommunal kontext, värdegrunder hos de svarande m.m. analyseras.

\section{Beslutsfattande och prioriteringar}

Att prioritera innebär "att rangordna" eller "att sätta före» (Callahan 1987), i regel genom att väga olika typer av behov gentemot varandra (Calltorp 1989). Prioriteringar i offentlig verksamhet grundar sig på mer eller mindre medvetna val utifrån föreställningar om vilka behov och krav som föreligger, vilken legitimitet dessa har och vilka insatser samhället har att erbjuda. Inom socialtjänsten förutsätter politikers och tjänstemäns arbete med prioriteringar dessutom ett hänsynstagande till lagstiftning och lokala regler/riktlinjer på området (Bergmark 1997, Bergmark 1995, Liss 2002, Socialstyrelsen 2004b). Ofta betonas att övervägandena bör vara grundade på människors behov samt öppna för alla som på något sätt är involverade. Prioriteringsbeslut i offentlig sektor bör vidare vara någorlunda tydliga för medborgarna, samt innehålla distinkta alternativ för de beslutsfattare som skall göra prioriteringarna, i synnerhet när resurser är knappa och måste ransoneras (Bergmark 1995, Bjurström et al. 2002, Frankena 1976, Liss 2002, Lund 2003). Andra värden som brukar framhållas är rättvisa och jämlikhet (Bergmark 1995, Dørup et al. 1996, Martin et al. 2002). Att omsätta detta i praktiskt 
handlande är dock i regel förenat med stora svårigheter, då rättvisa och jämlikhet är relativa företeelser och dessutom begrepp som i förstone inte är menade att skapa konsensus (Bergmark 1996, Martin et al. 2002, Sen 1992, Temkin 2003). De beslut som fattas handlar i realiteten ofta mer om avvägningar mellan personliga preferenser, professionella uppfattningar, kommunens egna riktlinjer och det nationella regelverket (Dørup et al. 1996, Elster 1992, Ham 1997). Martin et al. (2001) menar att prioriteringar kräver att de yttersta beslutsfattarna (i kommunernas fall politiker) försöker nå konsensus i prioriteringsprocessen - ett tillstånd där alla antingen kan instämma i beslutet eller åtminstone att alla kan anse att beslutet är fattat utifrån ett genomarbetat underlag och därigenom acceptabelt. Verkligheten ser emellertid i regel annorlunda ut. Tidsbrist, avsaknad av faktaunderlag samt den inneboende logik som präglar det politiska beslutsfattandet innebär att motiven bakom en given resursfördelning inte alltid, ens för de inblandade, är så tydliga.

Socialtjänsten är en ramlagsstyrd verksamhet vilket innebär att lagen ger en viss fingervisning om hur prioriteringar bör göras, men det är inte alltid lätt att omsätta dessa lagar i reella beslut. Grundläggande är dock att lagstiftningen ålägger kommunerna att bedriva viss typ av verksamhet, men i regel utan närmare angivelser av omfattning eller kvalitet. Andra bestämmelser innehåller mer direkta uttryck för prioriteringstänkande, men är för den skull inte självklara rättesnören vid beslutsfattande. Det gäller t.ex. barnkonventionen vilken Sverige ratificerade 1989 och imple- menterade i svensk lagstiftning 1990, där det anges att barns bästa alltid skall komma i främsta rummet (SOU 1997:116).

I en brittisk studie på tjänstemän framgår bl.a. att dessa uttrycker behov av riktlinjer för prioriteringar, i syfte att kunna göra rättvisa och väl övervägda sådana (Clifford \& Williams 2002). Det som dock kan skönjas i annan forskning, är t ex att socialarbetares situation, befintliga regelverk och varierande behov hos en klientgrupp av komplex karaktär kan skapa variationer i beslut och prioriteringar, vilka kan vara svåra att anpassa till verktyg och modeller för prioriteringar, se t.ex. (Vigilante \& Mailick 1988).

Socialpolitikens mål är att skapa social trygghet, vilket skall ske genom skattefinansiering (Elmér et al. 1998). I en statlig utredning avseende prioriteringar inom hälso- och sjukvård (SOU 1995:5) formuleras ett antal grundläggande principer för hur prioriteringar skall göras; behovsprincipen, meriteringsprincipen och kostnadseffektivitetsprincipen. Behovsprincipen innebär att prioriteringar skall utgå från individens behov, meriteringsprincipen att den som bäst förtjänar stödet eller kan använda det på bästa sätt också skall beredas förtur och kostnadseffektivitetsprincipen har som utgångspunkt att beslutsfattaren skall välja det alternativ som med minst kostnader tillgodoser individens behov på bästa sätt. Översätts dessa principer till att passa den svenska socialtjänsten och de lagrum den vilar på, så framstår behovsprincipen som mest central, med de båda andra som komplement till denna (Bergmark 1995, Socialstyrelsen 2004b). Inom sjukvården finns dock en väsentligt längre tradition att 
diskutera systematiska prioriteringsordningar, i syfte att underlätta för politiker och kliniskt verksamma praktiker (Calltorp 1989, Socialstyrelsen 2007b). Att skapa en sådan ordning kan förvisso tyckas enklare i sjukvården än i socialtjänsten med tanke på de mer uppenbart livshotande tillstånd som kan förekomma i sjukvården och som torde gå före åkommor av mindre allvarlig art och det faktum att det totalt sett finns mer kunskaper om effekter av olika interventioner. Därmed inte sagt att de prioriteringsordningar som upprättats där faktiskt får genomslag i sjukvårdspolitiska eller kliniska beslut.

Internationellt har behovet av ökad forskning inom området prioriteringar i socialtjänsten påtalats. Grundläggande för detta är uppfattningen att ökade kunskaper om och en mer utvecklad diskussion kring dessa frågor skulle göra det lättare för beslutsfattare att fatta väl övervägda beslut och, där så är önskvärt, uppnå en högre grad av rättvisa mot enskilda individer. Initialt förordas en mer deskriptiv forskning för att stadfästa forskningsfältet och sedan utgå från detta i ytterligare studier (Judge \& Mays 1994, Lund 2003, Mossialos \& King 1999).

I Sverige finns ett par studier genomförda på området prioriteringar i socialtjänsten, en studie gjord under 1990-talet (Bergmark 1995) och en genomförd under 2000-talet (Petersson 2006). I Peterssons studie utnyttjas ett upplägg som till stora delar sammanfaller med det som ursprungligen användes av Bergmark (a.a.). Peterssons studie avser endast äldreomsorg, medan Bergmarks studie inbegriper hela socialtjänsten men med huvudsakligt fokus mot individ- och familjeomsorg. Bägge studierna utgår till största delen från enkäter ställda till tjänstemän och politiker i de olika kommunerna. Av resultaten från bägge studierna framkommer att det föreligger skillnader mellan politiker och tjänstemän när det gäller sådant som vilka grupper som bör prioriteras vid ökade resurser och var nedskärningar är möjliga att genomföra. Socialarbetarna i Bergmarks studie tenderar framför allt att prioritera barn och unga, dels för att dessa betraktas som en grupp viktig att satsa på inför framtiden och dels för att de, framför allt mindre barn, ses som en försvarslös grupp som saknar ansvar för att problem uppstått. Klienter i behov av ekonomiskt bistånd eller, i synnerhet, missbrukarvård får en betydligt sämre uppbackning. De politiska beslutsfattarna i Bergmarks studie värnar framför allt om äldreomsorgen, ser minst möjligheter att göra besparingar i denna verksamhet samt vill satsa ytterligare resurser här. Också i Peterssons material tenderar politikerna att rangordna äldres behov högst, även om "barn och ungdomar generellt" kommer på andra plats.

\section{Urval och tillvägagångssätt}

Studien bygger på ett enkätmaterial riktat till tjänstemän och politiker inom socialtjänsten i sex svenska kommuner. Kommunerna är i storleksordningen 20000 till 65000 invånare. Den valda kommunstorleken är dels praktiskt, dels metodologiskt motiverad. De praktiska skälen handlar om att få hanterbara enheter och metodologiskt finns det anledning att arbeta med 
storleksmässigt relativt homogena kommuner. Inom detta intervall, vilket totalt omfattar 95 kommuner i landet, har sedan ett strategiskt urval gjorts på grundval av förändringar i kostnader för vissa insatser (individ- och familjeomsorg) eller täckningsgrad avseende olika stöd (äldreomsorg) under perioden 2002-2004. För individ- och familjeomsorgen har fokus för urvalet varit utvecklingen inom barnavård respektive missbrukarvård. För vart och ett av områdena har en kommun med påtagligt ökade och en med påtagligt minskade kostnader för perioden tagits fram.1 För äldrevården har sedan, på ett likartat sätt, två kommuner valts ut, med en ökning respektive minskning i andel äldre $(80+)$ med hemtjänst eller särskilt boende under perioden. I det slutliga urvalet togs sedan, av ekonomiska- och bekvämlighetsskäl, hänsyn till kommunernas geografiska placering. Under projektets genomförande föll sedan en kommun bort, vilken var den kommun som valts ut på grundval av en minskning $i$ andel äldre (80+) med hemtjänst eller särskilt boende. Slutligen ingår en kommun som deltog i den pilotstudie som föregick den mer omfattande datainsamlingen. Denna kommun valdes utifrån bekvämlighetsskäl, då syftet med pilotstudien var att testa enkäten. Dock är kommunen storleksmässigt inom samma intervall som övriga i urvalet. Det som skedde med enkäten efter pilotstudien var att vissa frågor rensades

1 Urvalet har gjorts inom den kvartil som ökat respektive minskat sina kostnader mest, med hänsyn taget till utvecklingen av sk standardkostnader (Socialstyrelsen 2004a) som är ett mått på utvecklingen av behoven $i$ kommunen. bort. I föreliggande artikel analyseras inte kommunala skillnader systematiskt (vilket dock kommer att ske i kommande artiklar) varför de problem som uppstått i samband med kommunurvalet inte har något avgörande inflytande på resultaten.

Enkäten har besvarats av sammanlagt 545 respondenter, 354 tjänstemän samt 191 politiker i de aktuella kommunerna. Tjänstemännen kommer i föreliggande artikel benämnas »ifo-tjänstemän« (tjänstemän inom individ- och familjeomsorg) och "voms-tjänstemän« (tjänstemän inom både äldreomsorg samt omsorg av psykiskt och fysiskt funktionshindrade, dvs. »vård- och omsorg«). Ett grundläggande kriterium för tjänstemannaurvalet har varit att dessa skall inneha tjänster med någon form av myndighetsutövning. För ifo-tjänstemännen innebär detta t.ex. handläggning av ekonomiskt bistånd eller insatser för vård av missbrukare. För voms-tjänstemän innebär detta exempelvis handläggning av bistånd i hemmet (s.k. hemtjänst) eller personlig assistans. Politikergruppen innefattar både facknämnder (socialnämnd eller motsvarande) och kommunstyrelse i de utvalda kommunerna.

Datainsamlingen har företrädesvis genomförts under ordinarie personalmöten samt arbetsplatsträffar och nämndssammanträden, i syfte att inte inskränka i det dagliga arbetet $i$ alltför stor omfattning. Under dessa träffar har personalen och nämndsledamöterna givits information om studien samt fyllt i enkäten individuellt. Icke närvarande har fått enkäter tillskickade sig och vid behov har påminnelser sänts ut. Detta förfarande har gett en hög svarsfrekvens (94 procent) samt, tack vare fors- 
karens närvaro och möjlighet att svara på eventuella frågor, ett lågt internbortfall och möjlighet att undvika missförstånd med enkätens frågor och studiens syfte. Datainsamlingen genomfördes huvudsakligen under hösten 2006. Politikernas enkätsvar inhämtades uteslutande från den nämndsorganisering som gällt under mandatperioden 2003-2006.

Olika analyser har genomförts i de olika resultatredovisningarna i syfte att passa de respektive frågeställning.

\section{Resultat}

Sett till bakgrundsfaktorer har de båda tjänstemannagrupperna vissa likheter, t.ex. att de består av en betydligt högre andel kvinnor än män. Detta är inte fallet i politikergruppen, vilken har en relativt jämn könsfördelning. Lägst medelålder av de tre grupperna har ifo-tjänstemännen (44 år), medan politikergruppen är väsentligt äldre (56 år). Detta återspeglas också i att politikerna har haft sina uppdrag längst tid, medan ifo-tjänstemännen innehaft sina tjänster kortast tid. Tjänstemännen inom vård- och omsorg skiljer sig gentemot IFO i det att den innefattar fler med chefsfunktioner.

\section{Förutsättningarför beslutsfattande och prioriteringar}

Prioriteringar handlar, som tidigare angetts, om beslutsfattande. Besluten inom socialtjänsten tas till stor del på tjänstemanna- nivå, via s.k. delegationsbeslut. Tjänstemän inom individ- och familjeomsorg är tydliga exempel på s.k. "gräsrotsbyråkrater" (street-level bureaucrats) vilket medför att de ofta har ett betydande handlingsutrymme att avgöra vem som har rätt till hjälp och i hur stor utsträckning hjälpen skall erbjudas (Handler \& Hasenfeld 1991, Lipsky 1980). Vilka förutsättningar tjänstemän har för sina beslut blir i och med detta viktig i en redogörelse för prioriteringar.

I Tabell 1 redovisas vilken betydelse tjänstemännen tillmäter olika former av extern styrning respektive sina egna överväganden i sitt beslutsfattande. Genom svaren speglas inte bara det generella handlingsutrymme de svarande anser sig ha, utan också vad som jämförelsevis anses viktigast och hur de bägge tjänstemannagrupperna skiljer sig åt.

Av tabellen framgår med tydlighet socialtjänstens karaktär av lagstyrd verksamhet. $A v$ i stort sett samtliga anges "lagstiftning" som mycket viktigt för de beslut man fattar. Som s.k. "gräsrotsbyråkrater" besitter tjänstemännen med andra ord inte någon ovillkorlig eller gränslös handlingsfrihet. Det är snarare så att lagar och även interna regler och riktlinjer (om än ej med samma kraft) ytterst definierar var gränserna för enskilda tjänstemäns handlingsdomän går (Dworkin 1977). Inom ramen för föreliggande studie kan vi emellertid inte mer än antyda dessa gränser. Mönstren för de två tjänstemannagrupperna är påfallande lika, med undantag för sparbeting och politikermål, vilka bägge har en signifikant större betydelse för tjänstemän inom vård och omsorg - vilket antyder att detta totalt sett 
är en mer politikerstyrd sektor. I stort kan vi emellertid konstatera att de flesta faktorer ses som betydelsefulla av tjänstemännen. De omständigheter som skiljer ut sig en aning i relation till de andra och ses som mindre betydelsefulla, är tjänstemännens egna "personliga åsikter" samt "sparmål/ betingu. Brukarnas synpunkter och tjänstemännens egen uppfattning ses också - i jämförbar grad - som betydelsefulla, vilket ligger i linje med Peterssons resultat (2006). Att framhålla brukarnas åsikter kan dock vara ett uttryck för politisk korrekthet svaret, vilket kan ge en överskattning av dess reella betydelse.
En ytterligare illustration av tjänstemännens handlingsfrihet och villkor framträder i Tabell 2, där de redogör för sin arbetssituation utifrån omständigheter som på olika sätt utgör ramar för vilka beslut de fattar och hur de bedriver sitt arbete.

En signifikant skillnad som framkommer är att ifo-tjänstemännen i högre grad anger att de har frihet att bestämma vad som skall utföras i arbetet. Detta kan härledas till hur de olika tjänstemännens myndighetsutövning ser ut. Voms-tjänstemännen har en mer given ram för sin myndighetsutövning, medan ifo-tjänstemännen har ett bredare batteri av insatser som de kan använda sig

\section{Tabell I.}

Angivelse av hur betydelsefull a följande olika faktorer är för de beslut tjänstemännen fattar $i$ sitt arbete. Procent (voms=vård och omsorg, ifo=individ- och familjeomsorg).

\begin{tabular}{|c|c|c|c|c|c|c|c|c|c|c|}
\hline & & $\begin{array}{l}\text { Mycket } \\
\text { viktigt }\end{array}$ & & $\begin{array}{c}\text { Ganska } \\
\text { viktigt }\end{array}$ & & $\begin{array}{l}\text { Ej så } \\
\text { viktigt }\end{array}$ & & $\begin{array}{c}\text { Helt } \\
\text { betydelse- } \\
\text { löst }\end{array}$ & & \\
\hline & $\begin{array}{c}n= \\
\text { voms/ifo }\end{array}$ & voms & ifo & voms & ifo & voms & ifo & voms & ifo & $\mathbf{p}^{*}$ \\
\hline $\begin{array}{l}\text { - Interna regler } \\
\text { och riktlinjer }\end{array}$ & $122 / 224$ & 42 & 54 & 51 & 42 & 7 & 4 & 0 & 0 & n.s \\
\hline - Lagstiftning & $125 / 227$ & 95 & 96 & 4 & 4 & 0 & 0 & 0 & 0 & n.s \\
\hline $\begin{array}{l}\text { - Direktiv från } \\
\text { chef/ledning }\end{array}$ & $125 / 222$ & 46 & 51 & 49 & 47 & 5 & 3 & 0 & 0 & n.s \\
\hline $\begin{array}{l}\text { - Brukarnas } \\
\text { synpunkter }\end{array}$ & $125 / 225$ & 69 & 61 & 30 & 35 & I & 4 & 0 & I & n.s \\
\hline $\begin{array}{l}\text { - Politikernas } \\
\text { uttalade mål }\end{array}$ & $122 / 225$ & 47 & 30 & 43 & 45 & 9 & 23 & 0 & 2 &, 000 \\
\hline $\begin{array}{l}\text { - Sparmål/spar- } \\
\text { beting }\end{array}$ & $123 / 225$ & 26 & | | & 43 & 45 & 23 & 39 & 7 & 5 &, 001 \\
\hline $\begin{array}{l}\text { - Din egen } \\
\text { professionella } \\
\text { uppfattning }\end{array}$ & $124 / 226$ & 68 & 67 & 28 & 31 & 3 & 2 & 0 & 0 & n.s \\
\hline $\begin{array}{l}\text { - Din personliga } \\
\text { uppfattning }\end{array}$ & | 24/227 & 20 & 14 & 36 & 36 & 30 & 40 & 13 & | | & n.s \\
\hline
\end{tabular}

${ }^{*}$ Mann Whitney's U-test; n.s= not significant 
av. $\AA$ andra sidan anger ifo-tjänstemännen i lägre grad att de har insyn i det politiska arbetet i sin kommun. Bägge resultaten kan möjligen återföras på den högre grad av politisk styrning som kunde iakttas i föregående tabell. Vidare är ifo-tjänstemännen en mer sammansatt grupp och mängden frågor som politiskt aktualiseras i anslutning till deras arbete kan vara svårare att överblicka. I övrigt uppvisar de båda tjänstemannagrupperna ett likartat mönster. En relativt stor andel av tjänstemännen anger att de har tillräcklig tid att hinna med sina arbetsuppgifter, men samtidigt också att deras arbete präglas av motstridiga krav.
Runt 90 procent anser dock att de har stor frihet att bestämma hur arbetet skall utföras. Det starka inflytande från lagar och riktlinjer vi kunde iaktta i Tabell 1 hindrar med andra ord tjänstemännen från att själva välja tillvägagångssätt.

I Tabellerna 1 och 2 har vi kunnat se hur tjänstemännen uppfattar sina arbetsvillkor och sitt handlingsutrymme. Det är nu dags att i Tabell 3 se hur politikerna ser på sina möjligheter att påverka besluten och på utrymmet för väl övervägda prioriteringsbeslut.

Tabell 2.

Tjänstemännens kontroll över arbetet och insynen i politiken. Procent

\begin{tabular}{|c|c|c|c|c|c|c|c|c|c|c|}
\hline & & $\begin{array}{c}\text { Ja, } \\
\text { absolut }\end{array}$ & & $\begin{array}{c}\text { Ja, } \\
\text { istort }\end{array}$ & & $\begin{array}{c}\text { Nej, } \\
\text { knappast }\end{array}$ & & $\begin{array}{c}\text { Nej, } \\
\text { absolut } \\
\text { inte }\end{array}$ & & \\
\hline & voms/ifo & $\begin{array}{c}\mathrm{n}= \\
\text { voms }\end{array}$ & ifo & voms & ifo & voms & ifo & voms & ifo & p* \\
\hline $\begin{array}{l}\text { - Tillräcklig tid att } \\
\text { hinna med sina } \\
\text { arbetsuppgifter? }\end{array}$ & $126 / 226$ & 2 & 7 & 50 & 48 & 37 & 31 & 11 & 14 & n.s \\
\hline $\begin{array}{l}\text { - Motstridiga krav } \\
\text { i sitt arbete? }\end{array}$ & $123 / 226$ & 16 & 16 & 49 & 38 & 33 & 42 & 2 & 4 & n.s \\
\hline $\begin{array}{l}\text { - Stor frihet att } \\
\text { bestämmaVAD } \\
\text { som skall utföras i } \\
\text { arbetet }\end{array}$ & $126 / 228$ & 10 & 15 & 58 & 64 & 30 & 20 & 2 & I &, 014 \\
\hline $\begin{array}{l}\text { - Stor frihet att } \\
\text { bestämma HUR } \\
\text { arbetet skall utfö- } \\
\text { ras? }\end{array}$ & I26/227 & 19 & 18 & 74 & 70 & 8 & II & 0 & 0 & n.s \\
\hline $\begin{array}{l}\text { - Insyn i det } \\
\text { politiska arbetet i } \\
\text { sin kommun? }\end{array}$ & I26/226 & 10 & 8 & 57 & 40 & 30 & 45 & 4 & 8 & ,002 \\
\hline
\end{tabular}

${ }^{*}$ Mann Whitney's U-test; n.s= not significant 


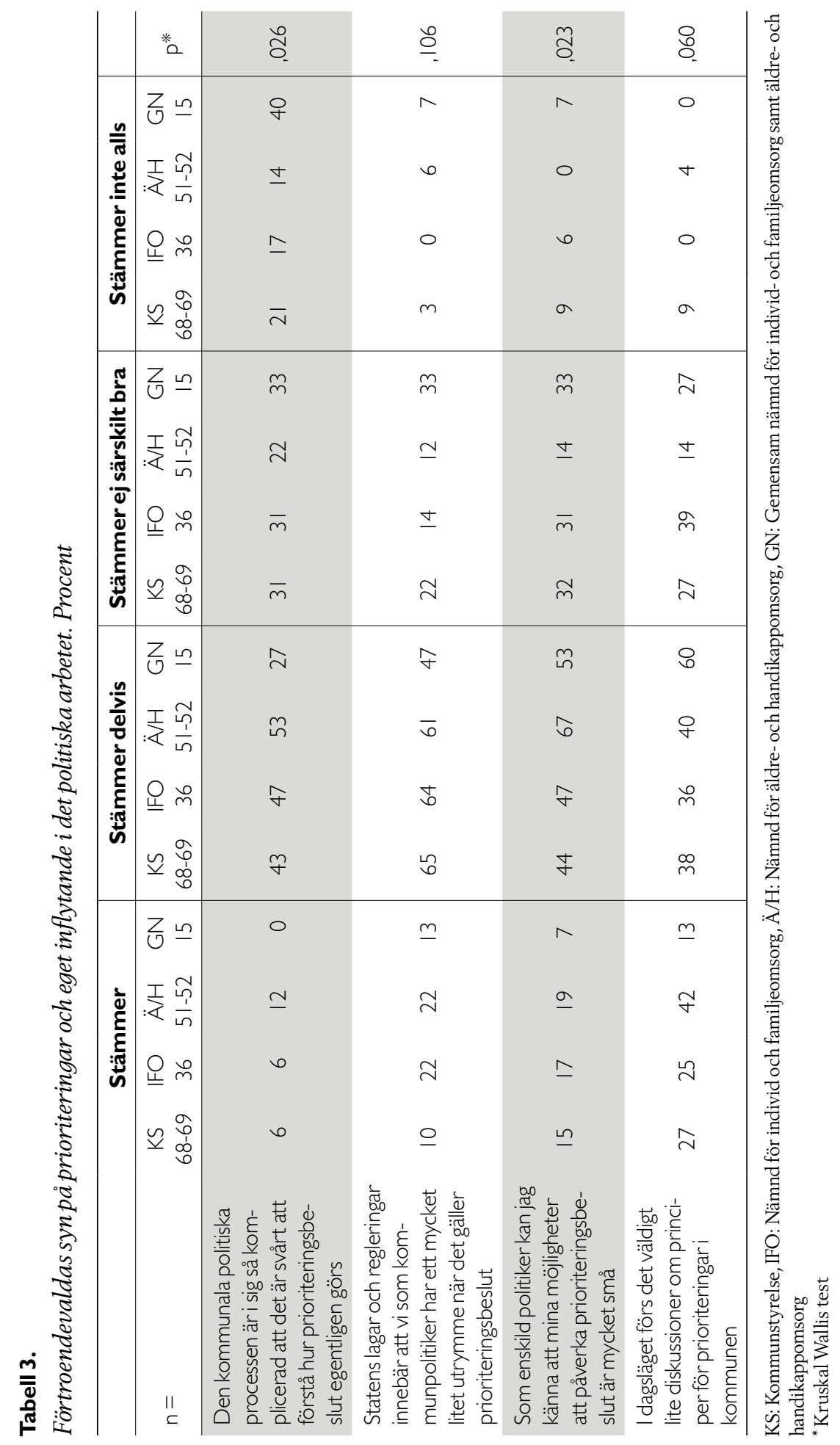

Socialvetenskaplig tidskrift nr $1 \bullet 2010$ 
Som vi kan se i Tabell 3 anser drygt hälften av politikerna, oavsett nämndstillhörighet, att den kommunala politiska processen är så komplicerad att de har svårt att förstå hur prioriteringsbesluten genomförs. Undantag utgörs av politiker verksamma i gemensam nämnd för individ- och familjeomsorg samt äldre- och handikappomsorg, medan politiker i äldreoch handikappsnämnd upplever de största svårigheterna. Mellan 60 och 86 procent av politikerna anser också att den styrning som staten utövar via lagar medför att politikerna har ett litet utrymme för prioriteringar. En klar majoritet av respondenterna anser också att deras möjligheter att påverka prioriteringsbesluten överhuvudtaget är små. Här utmärker sig särskilt politiker i nämnder som ansvarar för äldreomsorg och handikappomsorg, där närmare nio av tio instämmer i påståendet. Noterbart är också att när svaren ställs mot kön istället för nämndtillhörighet, framkommer att kvinnorna i studien anser sig ha mindre möjlighet att påverka prioriteringsbeslut än vad männen anser sig ha $(p=, 008) 2$. Noterbart är också att de allra flesta svarande menar att det förs väldigt lite diskussioner om principer för prioriteringar. Även här är det framförallt politiker inom äldre- och handikappnämnder som utmärker sig med höga nivåer. Enligt Socialstyrelsen (2007b) framkommer dessutom att det mestadels är chefstjänstemän i Sveriges kommuner som initierar diskussioner kring socialtjänstens uppbyggnad. Politikerna gör sällan så. Detta kan vara en följd av att politikerna

2 Mann-Whitney's U-test har känslan av att de inte kan påverka de beslut som fattas.

Några av förutsättningarna för tjänstemännens och politikernas arbete i kommunen de verkar i har således redovisats. I båda grupperna framkommer svar som dels visar på att tjänstemännen upplever att de har inflytande över vissa typer av beslut och dels visar på att detta inflytande är kringgärdat av lagar, lokala regelverk och andra omständigheter. Från detta kan vi övergå till att titta på hur tjänstemännen uppfattar kommunens resurser och i vilken omfattning grupperna faktiskt gör prioriteringar.

\section{Resurser och prioriteringar}

De flesta tjänstemän är av åsikten att den verksamhet de verkar inom inte bedrivs med helt tillräckliga resurser (ej redovisat i tabell). Ungefär en femtedel av respondenterna anger dessutom att de anser att resurserna är helt otillräckliga. Det finns tendenser till ett högre missnöje för vården av funktionshindrade och då särskilt inom gruppen som arbetar just med funktionshindrade, men även till stor del bland de tjänstemän som arbetar inom äldreomsorgen. Mot bakgrund av hur lagarna kring funktionshinder och äldreomsorg är utformade, är utfallet en aning oväntat. Funktionshindrade har oftast bistånd enligt LSS och LASS, vilka båda ger brukaren rätt till god levnadsnivå, medan bistånd enligt SoL som de flesta brukare inom äldreomsorgen omfattas av, endast ger brukaren rätt till skälig levnadsnivå. LASS ger dessutom brukaren rätt att själv välja personal, vilket torde vara positivt. 
En viktig del av tjänstemännens prioriteringsbeslut kommer till uttryck i deras direkta klientarbete. Närmast skall vi därför titta på hur ofta tjänstemän anser sig göra prioriteringar och om de någon gång under de senaste tre månaderna tvingats avstå från insatser som de för ett par år sedan skulle ha utfört.

Närmare tre fjärdedelar av respondenterna anger att de tvingas göra prioriteringar i sitt arbete ofta eller ganska ofta. Andelen är något högre bland voms-tjänstemännen, vilket möjligen skulle kunna framstå som paradoxalt i förhållande till utfallet i Tabell 2, där de som handlägger ärenden inom vård och omsorg i något lägre grad anser att de har frihet att bestämma innehållet i sitt arbete. Sambandet mellan prioriteringar och handlingsfrihet är dock komplext. Dessa resultat ligger i ungefär samma linje som Bergmarks resultat från 1990talet (Bergmark 1995). På en följdfråga om vilken sorts prioriteringar tjänstemännen behövt göra, har de flesta ifo-tjänstemän angett avvägningar avseende hur mycket arbetstid som skall avsättas för olika ären- den. Många, också voms-tjänstemän, anser att de också rent turordningsmässigt prioriterar mellan klienter. Tilldelningen av resurser till olika områden är naturligtvis en omständighet som bidrar till att sätta ramar för vilken typ av insatser som tjänstemännen kan tillhandahålla. Ett ökat kostnadstryck bör därför, logiskt sett, innebära att vissa åtgärder mer sällan blir utförda och att behovsprövningen på det hela taget blir hårdare. I relation till vad som skrivits ovan om tjänstemännens syn på resurstilldelning, är det intressant att ta reda på hur tjänstemännen upplevt utvecklingen i verksamheten med ett perspektiv bakåt. Tjänstemännen anger också i hög grad att de inte behövt avstå från insatser som de tidigare kunnat genomföra. Det är endast elva procent av ifo-tjänstemännen som anger att de tvingats avstå från någon åtgärd som de tidigare kunnat utföra, att jämföras med åtta procent av voms-tjänstemännen. Tidsperspektivet är givetvis av vikt här, då de allra senaste åren innan enkätens genomförande inte präglats av det slag av tydliga besparingar som annars dominerade

\section{Tabell 4.}

Tjänstemäns upplevda erfarenheter av prioriteringar. Procent

\begin{tabular}{|c|c|c|c|c|}
\hline & \multicolumn{2}{|c|}{$\begin{array}{l}\text { I vilken utsträckning man tvingas göra } \\
\text { prioriteringar i sitt arbete }(p=, 005)\end{array}$} & \multicolumn{2}{|c|}{$\begin{array}{l}\text { I vilken utsträckning man av kostnads } \\
\text { skäl avstått från insatser man tidigare } \\
\text { skulle ha utfört }(p=, 064) \text { | }\end{array}$} \\
\hline & ifo $n=225$ & voms $n=126$ & ifo $n=156$ & voms $n=108$ \\
\hline Ofta & 33 & 40 & 1 & 3 \\
\hline Ganska ofta & 38 & 44 & 10 & 5 \\
\hline Någon enstaka gång & 19 & 13 & 28 & 23 \\
\hline Aldrig/Nästan aldrig & 5 & 2 & 62 & 70 \\
\hline $\begin{array}{l}\text { Arbetar ej med } \\
\text { klienter }\end{array}$ & 5 & 0 & - & - \\
\hline
\end{tabular}

Signifikans prövad med Mann Whitneys's U-test 
utvecklingen under 1990-talskrisen och en tid framåt (Ackerby \& Åkerlund 2004). Bland ifo-tjänstemännen är det 62 procent som angett att de aldrig eller nästan aldrig tvingats avstå från åtgärder, vilket kan jämföras med 46 procent ett drygt decennium tidigare (Bergmark 1995). Inga betydande skillnader framträder mellan de bägge tjänstemannakategorierna, även om det finns en (signifikant) tendens till att de inom vård och omsorg mer sällan fått avstå från tidigare givna insatser. Ett resultat som givetvis också kan hänga ihop med det bredare spektrum av insatser som förekommer inom IFO.

\section{Satsningar och besparingar $i$ socialtjänsten}

Ett underliggande antagande i studien är att såväl politiker som tjänstemän är viktiga för hur fördelningen av insatser utformas inom socialtjänsten eller inom ramen för enskilda verksamhetsområden. Därför finns det anledning att tro att deras önskemål eller preferenser avseende tilldelning av resurser kan ha relevans för utvecklingen på sikt. Härnäst redogörs för hur respondenterna önskar göra prioriteringar mellan olika klientgrupper och verksamhetsområden.

Tabell 5 blottlägger ett antal tydliga

\section{Tabell 5.}

Viktigaste grupper att satsa på i framtiden. Medelvärden i rangordning*

\begin{tabular}{|c|c|c|c|c|c|}
\hline & $\begin{array}{c}\text { Tjänstemän } \\
\text { ifo } \\
n=227\end{array}$ & $\begin{array}{c}\text { Tjänstemän } \\
\text { voms } \\
n=124\end{array}$ & $\begin{array}{c}\text { Politiker } \\
n=187\end{array}$ & Total & \\
\hline & $\mathbf{m}$ & $\mathbf{m}$ & $\mathbf{m}$ & $\mathbf{m}$ & $\mathrm{p}^{* *}$ \\
\hline Äldre generellt &, 33 & 1,19 & 93 & 81 &, 000 \\
\hline Äldre över 80 år & ,09 &, 24 &, 40 &, 24 &, 000 \\
\hline Barn och ungdomar generellt & 2,03 & 1,48 & 1,58 & 1,75 &, 000 \\
\hline Förskolebarn &, 46 & ,09 &, 17 &, 27 &, 000 \\
\hline $\begin{array}{l}\text { Ungdomar med sociala problem } \\
\text { inkl deras familjer }\end{array}$ & 1,15 & ,77 & 1,02 & 1,02 &, 011 \\
\hline Arbetslösa generellt & ,38 &, 25 & ,39 &, 35 & n.s \\
\hline Arbetslösa ungdomar &, 68 &, 55 &, 74 & 67 & n.s \\
\hline Vuxna med missbruksproblem &, 10 & 04 &, 10 & ,09 & n.s \\
\hline $\begin{array}{l}\text { Vuxna med andra sociala eller } \\
\text { psykiska problem }\end{array}$ &, 27 &, 35 &, 12 &, 24 &, 001 \\
\hline Socialbidragstagare &, 10 &, 04 & ,05 & ,07 & n.s \\
\hline Invandrare/Flyktingar &, 18 &, 10 &, 18 &, 16 & n.s \\
\hline Funktionshindrade & ,07 &, 41 &, 28 &, 22 & 000 \\
\hline Andra &, 07 &, 06 & ,03 &, 06 & n.s \\
\hline
\end{tabular}

${ }^{*}$ Medelvärde (m) uträknat utifrån rangordnad i första till tredje hand av 13 grupper, poäng 0-3, varav rangordnad i första hand ger 3 poäng, $i$ andra hand 2 poäng och i tredje hand 1 poäng (ej rangordnad 0 poäng),

${ }^{* *}$ Anova; n.s= not significant 
mönster. Barn och ungdomar generellt rangordnas genomgående högst, synnerhet av ifo-tjänstemännen. Ifo-tjänstemännen är också de som i sitt dagliga arbete har mest direktkontakt med barn och unga. Även politiker och i någon mån voms-tjänstemän ger hög prioritet till barn och unga (med eller utan sociala problem). Möjligen kan man misstänka att det $\mathrm{i}$ frågan inskjutna „i framtiden" påverkar svaren i denna riktning. Voms-tjänstemännen tenderar också att stödja verksamheter inom det egna området. Framförallt gäller detta de äldre men också, i jämförelse med övriga, funktionshindrade. Klientgrupper som genomgående samlat låga poäng, är vuxna med missbruksproblem, socialbidragstagare, invandrare/flyktingar och funktionshindrade. Noterbart är att politikergruppen utmärker sig genom att i jämförelsevis lägre grad vilja satsa på vuxna med andra sociala eller psykiska problem.

För politiker är besparingsbeslut av olika slag en del av det politiska arbetet. I vilken utsträckning enskilda politiker görs delaktiga i den typen av beslut varierar naturligtvis, men på det hela taget finns det skäl att tro att synen på var det går, respektive inte går att genomföra besparingar är av stor betydelse för resursutvecklingen på olika områden. I Tabell 6 framgår hur politikerna i studien ser på besparingar i socialtjänstens verksamheter.

Generellt i Tabell 6 kan vi utläsa att den verksamhet som politikerna anser att det skulle finnas möjligheter att spara inom, i första hand är ekonomiskt bistånd. Påfallande många har också svarat här att de inte vet, vilket dels kan bero på rådvillhet, dels också på en politiskt grundad ovilja att tydliggöra negativa prioriteringar. Att politikerna anger att de inte vet, skulle kunna vara en återspegling av vad vi såg $i$ Tabell 3 , att många politiker anser att det ej förs tillräckliga diskussioner kring just prioriteringar. Icke desto mindre är detta oroande, då politikerna är den grupp som bör vara på det klara med hur verksamheten skall förvaltas. De flesta politiker är eniga om att barn- och ungdomsvård samt äldrevård är svåra områden att göra besparingar inom. Politiker i nämnder för äldre- och handikappomsorg har i lägre grad angett barn- och ungdomsvård och i högre grad äldrevård. Detta behöver inte vara anmärkningsvärt i sig, då vi redan tidigare, i samband med Tabell 4 diskuterat möjligheterna att vilja verka där man står, så att säga. Tendenser till att vilja skydda "egna» domäner från besparingar finner vi också bland politiker med ansvar för individ- och familjomsorg.

På frågan om hur besparingar kan ske har politikerna svarat har de flesta uppgett "genom förebyggande arbete» samt "genom effektiviseringar». Ytterst få har velat tala om nedskärningar, vilket återigen kan vara ett uttryck för hur negativt ett sådant begrepp klingar bland politiska beslutsfattare.

\section{Diskussion}

Sveriges kommuner är autonoma och sanktioneras beslutanderätt från staten. Varje kommun har sin egen målsättning för verksamheten vilket genererar skillnader i tillgänglighet och service. Av studien framgår emellertid att socialtjänsten i hög grad är och uppfattas som en lagstyrd 
verksamhet. Trots detta upplever många av tjänstemännen att deras arbetsuppgifter innehåller motstridiga krav. De lagar som skall styra socialtjänsten är i huvudsak av ramlagskaraktär vilket $\mathrm{i}$ stor omfattning ger kommunerna och tjänstemännen ett

\section{Tabell 6.}

Politikers syn på besparingar i verksamheten, nämndvis uppdelning. Procent

\begin{tabular}{|c|c|c|c|c|}
\hline & $\begin{array}{c}K S \\
n=66\end{array}$ & $\begin{array}{l}\text { IFO } \\
n=36\end{array}$ & $\begin{array}{l}\mathrm{A} / \mathrm{H} \\
\mathrm{n}=53\end{array}$ & $\begin{array}{c}\text { GN } \\
n=15\end{array}$ \\
\hline \multicolumn{5}{|l|}{$\begin{array}{l}\text { På vilket område tycker du att det idag finns störst } \\
\text { möjligheter att åstadkomma besparingar utan att } \\
\text { kvaliteten försämras? }\end{array}$} \\
\hline - Missbrukarvård & 12 & 14 & 9 & 7 \\
\hline - Barn- och ungdomsvård & 14 & 17 & 8 & 0 \\
\hline - Ekonomiskt bistånd & 29 & 28 & 30 & 73 \\
\hline - Äldrevård & 14 & 11 & 8 & 0 \\
\hline - Insatser för funktionshindrade i övrigt & 5 & 3 & 4 & 0 \\
\hline \multirow[t]{2}{*}{-Vet ej } & 27 & 28 & 42 & 20 \\
\hline & $\begin{array}{c}\mathrm{KS} \\
\mathrm{n}=63\end{array}$ & $\begin{array}{l}\text { IFO } \\
n=34\end{array}$ & $\begin{array}{l}\text { Ä/H } \\
n=46\end{array}$ & $\begin{array}{r}\mathbf{G N} \\
\mathbf{n}=13\end{array}$ \\
\hline \multicolumn{5}{|l|}{ Hur kan dessa besparingar genomföras? } \\
\hline $\begin{array}{l}\text { - Genom effektivisering av } \\
\text { verksamheter }\end{array}$ & 19 & 27 & 28 & 15 \\
\hline $\begin{array}{l}\text { - Genom att vissa mindre viktiga inslag } \\
\text { i verksamheter skärs ned på }\end{array}$ & 2 & 0 & 9 & 0 \\
\hline $\begin{array}{l}\text { - Genom strukturella insatser utanför } \\
\text { socialtjänsten }\end{array}$ & 22 & 15 & 7 & 15 \\
\hline - Genom mer förebyggande arbete & 49 & 44 & 44 & 54 \\
\hline \multirow[t]{2}{*}{ - På annat } & 8 & 15 & 13 & 15 \\
\hline & $\begin{array}{c}K S \\
n=67\end{array}$ & $\begin{array}{l}\text { IFO } \\
n=36\end{array}$ & $\begin{array}{c}\stackrel{A}{A} / H \\
n=52\end{array}$ & $\begin{array}{r}\mathbf{G N} \\
\mathrm{n}=17\end{array}$ \\
\hline \multicolumn{5}{|c|}{$\begin{array}{l}\text { På vilket område tror du det idag finns minst möjligheter att åstadkomma } \\
\text { besparingar utan att kvaliteten försämras? }\end{array}$} \\
\hline - Missbrukarvård & 9 & 6 & 4 & 7 \\
\hline - Barn- och ungdomsvård & 34 & 50 & 14 & 40 \\
\hline - Ekonomiskt bistånd & 12 & 11 & 4 & 0 \\
\hline - Äldrevård & 28 & 19 & 44 & 33 \\
\hline - Insatser för funktionshindrade i övrigt & 6 & 6 & 14 & 13 \\
\hline - På annat & 10 & 8 & 21 & 7 \\
\hline
\end{tabular}

KS: Kommunstyrelse, IFO: Nämnd för individ och familjeomsorg, Ä/H: Nämnd för äldre- och handikappomsorg, GN: Gemensam nämnd för individ- och familjeomsorg samt äldre- och handikappomsorg, $\mathrm{n}$ redovisar de respondenter som besvarat frågan

${ }^{*}$ Signifikans genomgåendet prövad med $\mathrm{Chi}^{2}$ 
betydande handlingsutrymme. Paradoxen lagstyrning-professionellt handlingsutrymme återspeglas i hög grad i de svar som tjänstemännen ger, där de å ena sidan vittnar om en betydande frihet, men å andra sidan i mycket lutar sig mot lagstiftningen i sitt beslutsfattande. Det är också nära till hands att föreställa sig att denna motsättning i hög grad är grunden till de svårigheter som genomsyrar beslutsprocessen.

Trots tjänstemännens upplevelse av motstridiga krav anser merparten att de har tillräckligt med tid för sitt arbete samt att de faktiskt inte behövt avstå från insatser pga ekonomi. Däremot känner många sig tvingade att prioritera i fråga om arbetstidsfördelning mellan ärenden. Vi bör hålla i minnet att data insamlats under 2006, när kommunerna återhämtat sig något efter 1990-talets finanskris.

Svårigheterna att förena motstridiga krav och göra väl övervägda prioriteringar gäller dock inte bara tjänstemännen. Majoriteten av studiens politiker anser att prioriteringsprocessen är komplicerad och att de enskilt har svårt att påverka beslutsfattandet. Vidare menar merparten av politikerna att det statliga regelverket i realiteten medger ett relativt litet utrymme för dem som kommunpolitiker att göra någon skillnad. Att det trots allt finns föreställningar hos de folkvalda om att prioriteringsarbetet skulle kunna utvecklas framgår av att politikerna i studien i hög grad anger att de saknar diskussioner kring prioriteringar. Möjligen finns det en osäkerhet kring vem som skall initiera sådana diskussioner eller under vilka former de skall genomföras. Socialstyrelsen (2007b) pekar just på det faktum att politiker ytterst sällan själva initierar diskussioner i ämnet.

Sett ur ett demokratiskt perspektiv är det politikerna i kommunerna som, vid sidan av tilldelningen av resurser, har till uppgift att formulera mål och riktlinjer för socialtjänsten. Tjänstemännen har i sin tur som uppgift att omsätta dessa mål och riktlinjer i verksamhet. En sådan ordning bygger på att signalerna från de kommunala beslutsfattarna är någorlunda tydliga och att de når de tilltänkta mottagarna. Flertalet tjänstemän i denna studie vittnar dock om dålig insyn i det politiska arbetet, något som var särskilt uttalat bland individ- och familjeomsorgens tjänstemän. Ett skäl till detta kan vara att IFO innehåller en mer sammansatt grupp av tjänstemän och att mängden frågor kan vara svårare att överblicka än inom vård och omsorg. Som vi kunde se i tabellerna 1 och 3 är resultaten $i$ viss mån paradoxala. Voms-tjänstemännen upplever äldreomsorgen som betydligt mer politiskt styrd jämfört med ifo-tjänstemännen. Samtidigt anser sig politikerna inom äldreomsorgsförvaltningarna ha ett mindre handlingsutrymme än övriga politikergrupper. Politikergrupperna, och då särskilt politiker i äldreomsorgen anser också att det inte förs tillräckliga diskussioner kring hur prioriteringar skall göras, vilket kan förklara att både tjänstemän och politiker känner sig rådvilla $\mathrm{i}$ frågan. En anledning till den bristande insynen mer allmänt kan vara att det saknas forum i den kommunala organisationen för möten mellan tjänstemän och politiker.

Ett tydligt mönster i studien är att barn/ unga och äldre är två grupper som framhålls som viktiga att resursmässigt satsa på 
respektive skona vid besparingar. Motsatt förhållande råder för socialbidragstagare, missbrukare, invandrare/flyktingar samt funktionshindrade, vilka kontinuerligt tenderar att hamna i prioriteringsdiskussionernas bakvatten. Med tanke på att klientgrupperna ställs mot varandra i enkäten är resultaten inte alltför oväntade. Fler tjänstemän arbetar dessutom med barn/ unga och äldre och det finns mönster i studien som pekar mot att "man satsar där man verkar". Dessa resultat skiljer sig heller inte nämnvärt mot tidigare resultat $\mathrm{i}$ svenska och internationella studier, se t.ex. Mossialos och King (1999) eller Bergmark (1995). Emellertid finns det olika resonemang kring varför. Mossialos och King menar att det uttalade stödet till förmån för de äldre beror på att de ses som den grupp som byggt upp samhället och därför har en moralisk rätt att få ta del av den välfärd de bidragit till, medan yngre å sin sida anses representera framtiden och därför - till allas vår nytta - bör ges företräde i prioriteringsöverväganden. Bergmark berör likartade skäl men anser också att skälen till detta mönster varierar. Det kan lika gärna bero på $t$ ex äldrevård historiskt sett varit försummad eller på att det saknas andra möjliga alternativ för dessa grupper. Gemensamt för merparten av de grupper som ges en lägre prioritet är att de potentiellt kan betraktas som "ovärdiga" mottagare av samhälleligt stöd då det kan finnas en beteendedimension i botten på deras problematik. Politikerna i studien talar dock ogärna om nedskärningar eller minskade resurser. Istället betonas kostnadsef- fektivitet, effektiviseringar och satsningar på förebyggande arbete. Motviljan mot att artikulera nedskärningsmål kan kanske ses som en del av den politiska retorikens grundläggande drag, där mer eller mindre välgrundade förhoppningar om ökad produktivitet får utgöra en utväg. Något som kan ha en "uppmjukande» effekt på politikernas svar är att enkätundersökningen genomfördes under upptakten och efterdyningarna till en valperiod (se t.ex. Dahlberg \& Mörk, 2008). Möjligen kan detta vara en förklaring till den ambivalens som vi tidigare sett i tabell 6 .

Tilldelningen av resurser blir ett villkor för de insatser som tjänstemännen kan tillhandahålla och i förlängningen avgörande för hur tillgängliga olika biståndsinsatser blir eller vilken kvalitet de har. Den försämrade ekonomi som Sveriges kommuner idag står inför kommer sannolikt att skärpa kraven på väl övervägda prioriteringar. Minskade resurser innebär generellt att behovsprövningen hårdnar och att förväntningarna på att icke offentliga insatser - marknad, frivilligsektor och familj träder in där kommunen kommer till korta. Beslutsfattare skulle genom att formulera distinkta alternativ för beslut kunna frambringa en mer enhetlig, tydlig och öppen bakgrund för prioriteringsbeslut.

Kommande artiklar inom ramen för föreliggande studie kommer att erbjuda mer fördjupade analyser av hur den kommunala kontexten och värderingsgrunder hos enskilda aktörer kan påverka de överväganden och beslut av prioriteringskaraktär som förekommer. 


\section{Referenser}

Ackerby, S. \& Åkerlund, M.-L. (2004) Kommunernas och landstingens ekonomiska läge: Svenska Kommunförbundet.

Bergmark, A. (1996) „Need, allocation and justice On priorities in the social services", Scandinavian Journal of Social Welfare, 5(1), pp. 45-56.

Bergmark, A. (1997) „From reforms to rationing? Current allocative trends in social services in Sweden", Scandinavian Journal of Social Welfare, 6(2), pp. 74-81.

Bergmark, A. (1995) Prioriteringar i socialtjänsten. Stockholm: Stockholms Universitet.

Bjurström N., Alaby G., \& Andersson M. (2002) Vem ska få vad?: en bok om politikerrollen $i$ äldreomsorgen. Stockholm: Gothia.

Callahan, D. (1987) Setting limits. Medical goals in an ageing society. New York: Simon and Schuster.

Calltorp, J. (1989) Prioritering och beslutsprocess $i$ sjukvårdsfrågor: några drag i de senaste decenniernas svenska hälsopolitik $=$ Priority-setting and the decision-making process in health care : some postwar characteristics of health policy in Sweden. Uppsala: Uppsala Universitet.

Clifford, D., \& Williams, G. (2002) „Important Yet Ignored: Problems of 'Experstice' in Emergency During Work", The British Journal of Social Work, 32(2), pp. 201-215.

Dahlberg, M., \& Mörk, E. (2008) Valår och den kommunala politiken (No. 2008:4). Uppsala: IFAU - Institutet för arbetsmarknadspolitiks utvärdering.

Dworkin, R. (1977) Taking rights seriously. London:

Dørup A. B., Holland K., \& Uggerhøj L. (1996) Lad målet styre midlerne: prioritering og arbejdsmetoder $i$ en socialforvaltning (2. opl. ed.). København: Munksgaard.

Elmér Å., Blomberg S., Harrysson L. \& Petersson, J. (1998) Svensk Socialpolitik (19 ed.). Lund: Studentlitteratur.

Elster, J. (1992) Local Justice. New York: Press Syndicate of the University of Cambridge.
Forsblom, P.-O. (2002) "Stick inte huvudet i sanden Morgan Johansson", Kommunaktuellt (39), s, 19.

Frankena, W. (1976) Perspectives on morality. Notre Dame: University of Notre Dame Press.

Ham, C. (1997) „Priority setting in health care: learning from international experience", Health Policy, 42(1), pp. 49-66.

Handler, J. \& Hasenfeld, Y. (1991) The Moral Construction of Poverty. Newbury Park:

Judge, K. \& Mays, N. (1994) „Equity in the NHS Allocating resources for health and social care in England", British Medical Journal(308), pp. 1363-1366.

Lipsky, M. (1980) Street-level Bureaucracy. Dilemmas of the individual in public services. New York: Russel Sage.

Liss, P.-E. (2002) Fördelning, prioritering och ransonering av hälso- och sjukvård - en begreppsanalys (No. 2002:4).

Lund, K. (2003) Öppna Prioriteringar i kommunernas vård och omsorg? (No. 2003:5). Linköping: Prioriteringscentrum.

Martin D. K., Giacomini M., \& Singer P. A. (2002) "Fairness, accountability for reasonableness, and the views of priority - setting desicionmakers", Health Policy, 61(3), pp. 279-290.

Mossialos, E., \& King, D. (1999) "Citizens and rationing: analysis of a European survey", Health Policy, 49(1-2), pp. 75-135.

Petersson, J. (2006) Prioriteringar och Processer $i$ socialtjänsten. Lund: University of Kalmar.

Sen, A. K. (1992) Inequality reexamined. New York, Cambridge, Mass.: Russell Sage Foundation; Harvard University Press.

Socialstyrelsen (2004a) Systematisk bedömning inom socialtjänsten (No. 2004-131-10). Stockholm: Socialstyrelsen.

Socialstyrelsen (2004b) Prioriteringar $i$ socialtjänsten. - En analys av rättsliga förutsättningar. Stockholm: Socialstyrelsen.

Socialstyrelsen (2007a) Lika olika socialtjänst? Kommunala skillnader $i$ prioritering, kostna- 
der och verksamhet (No. 2007-131-4). Stockholm: Socialstyrelsen.

Socialstyrelsen (2007b) Resursfördelning och prioriteringar inom socialtjänsten (No. 2007-110-

19). Stockholm: Socialstyrelsen.

SOU (1995:5) Vårdens svåra val: slutbetänkande. Stockholm: Fritzes.

SOU (1997:116) Barnets bästa i främsta rummet.
FN's konvention om barnets rättigheter i Sverige. Stockholm:

Temkin, L., S. (2003) „Egalitarianism Defended", Ethics, 113(July), pp. 764-782.

Vigilante, F. W. \& Mailick, M. D. (1988) „NeedsResource Evaluation in the Assessment Process", Social Work, pp. 101-104.

\section{Summary \\ Priorities in the social services \\ Autonomy in action and decision making in Swedish municipalities}

This article presents a study of social services in six Swedish municipalities. The study aims to illustrate politicians' and officials' opinions on priorities in their work and how they choose to prioritize among client groups. We then look at which factors can be important for decision making and how officials and politicians experience their influence on decision making. The results show that officials regard laws and regulations as important for their decision making, though the framework character of the legislation gives scope for substantial direction but also generates a complex situation with various demands and alternati- ves to decide between. The politicians feel segregated from the prioritizing process and think that there is too little in-depth discussion of the subject.

Priorities are regarded by the officials as a part of their daily work. These priorities do not only concern eligibility assessments but also how much time they should give each client or what clients to help first.

If we look at the priorities the informants express, children/adolescents and elderly people are given the highest ranking. Lowest priority is given to addicts, welfare recipients, refugees/immigrants and people with disabilities. 